\title{
Psychiatric leadership development in postgraduate medical education and training ${ }^{\dagger}$
}

\author{
Alex Till, ${ }^{1}$ (1) Radhika Sen, ${ }^{2,3}$ Helen Crimlisk ${ }^{2,4}$
}

BJPsych Bulletin (2022) 46, 174-181, doi:10.1192/bjb.2021.32

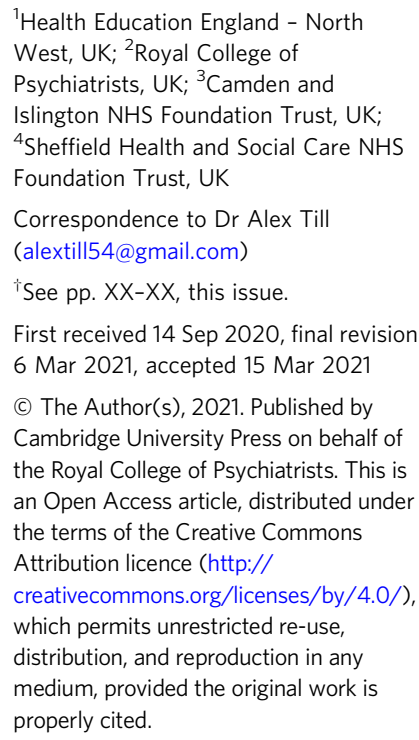

${ }^{1}$ Health Education England - North West, UK; ${ }^{2}$ Royal College of Psychiatrists, UK; ${ }^{3}$ Camden and Islington NHS Foundation Trust, UK; ${ }^{4}$ Sheffield Health and Social Care NHS Foundation Trust, UK

Correspondence to Dr Alex Till (alextill54@gmail.com)

'See pp. XX-XX, this issue.

First received 14 Sep 2020, final revision 6 Mar 2021, accepted 15 Mar 2021

(c) The Author(s), 2021. Published by Cambridge University Press on behalf of the Royal College of Psychiatrists. This is an Open Access article, distributed under the terms of the Creative Commons Attribution licence (http://

creativecommons.org/licenses/by/4.0/), which permits unrestricted re-use, distribution, and reproduction in any medium, provided the original work is properly cited.

\begin{abstract}
Summary The value of strong, compassionate medical leadership in the delivery of high-quality care to patients within mental health services is clear. Leadership development, however, is far less well explored. This article is for psychiatric trainees, trainers and mental health organisations. It provides an introduction to the importance of leadership development within postgraduate medical training, the theory that should underpin its delivery, and the opportunities for both informal and formal leadership development within psychiatric training.
\end{abstract}

Keywords Leadership; management; education and training; postgraduate.
Doctors are frequently the head of healthcare teams, ${ }^{1}$ with leadership an emergent theme within the skills, knowledge and behaviours required of our future doctors. ${ }^{2}$ Leadership is the most influential factor in shaping organisational culture. ${ }^{3}$ It must be compassionate to stimulate improvement and innovation, ${ }^{4}$ and is the hallmark of high-quality care. ${ }^{5}$

Leadership can be conceptualised as 'a process that occurs in a group context, involving the influence of others towards the attainment of a common goal'. ${ }^{6}$ Yet leadership is better conceptualised as a 'triad', whereby leadership, management and followership are distinct, but inextricably linked skills, and hereafter are considered as one.,

Leadership has been formally recognised as a responsibility for all doctors since $2012,{ }^{9}$ and is gradually being integrated into both undergraduate ${ }^{10}$ and postgraduate medical curricula. ${ }^{11}$ To help guide trainees' development within these domains, the Faculty of Medical Leadership and Management (FMLM) have produced standards for medical professionals ${ }^{12}$ that clearly outline four key domains for doctors:

(1) A doctor's ability to know and understand themselves and their impact on others.

(2) A doctor's ability to know when to lead and follow, and how to establish and lead teams.

(3) A doctor's ability to understand and positively contribute to the strategic direction and operational delivery of their organisation.
(4) A doctor's ability to understand and positively contribute to the healthcare system.

Despite this initiative, the relevance and importance of leadership development is yet to be fully embraced by the medical profession. It is often still perceived as an 'optional extra' within medical training, ${ }^{13}$ and an unpopular, unrewarding and risky 'add-on'. ${ }^{14}$ This lack of external validation, and outdated traditional view of medical professionalism, compromises the development of so-called 'willing hybrids', and the integration of leadership and managerialism as a legitimate and essential aspect of medical professionalism. $^{15,16}$

The argument for strong medical leadership within healthcare organisations is well defined. ${ }^{17,18}$ Mental health services face unprecedented challenges on an almost daily basis. Doctors must be engaged in leadership ${ }^{19}$ and with their organisations as a whole. ${ }^{20}$ They must be capable of understanding and overcoming the volatile, uncertain, complex and ambiguous ${ }^{21}$ nature of providing not only health, but also social care, within an increasingly integrated systems-based approach.

Leadership development, therefore, is crucial, yet far less well explored. There is little robust evidence for the effectiveness of specific leadership development programmes, with a proliferation of diverse interventions throughout medical training and healthcare as a whole. ${ }^{3}$ 
It is clear, however, that the systematic integration of basic leadership development for all doctors needs to be embedded throughout postgraduate medical training, supplemented by enhanced and advanced opportunities for aspiring medical leaders, and that trainees themselves need to realise and accept leadership responsibility.

This article is for psychiatric trainees, trainers and mental health organisations. It builds on the already established position highlighting the positive impact of psychiatrists on leadership and management. ${ }^{22}$ It provides an introduction to the importance of leadership development within postgraduate medical training, the theory that should underpin its delivery, and the opportunities for both informal and formal leadership development available to psychiatric trainees within postgraduate medical training throughout the UK.

\section{Leadership development theory}

Healthcare, like many other industries, often falls victim to the 'great training robbery'. ${ }^{23}$ Organisations frequently support and encourage individuals to undertake externally provided leadership development programmes, and yet often fail to provide appropriate conditions on their return for them to contextualise and apply their learning within their clinical environment. Although this can be successful in developing their knowledge, skills and competencies, it effectively sets them up to fail, and leads to the continuation of entrenched and established ways of working. ${ }^{24}$

If exclusively developed within the 'classroom', development will largely remain 'horizontal', 25 and leaders will fail to learn how to change and adapt to ever-changing circumstances. $^{23}$ Alternatively, an 'in vivo' approach, with the right conditions coordinated throughout a programme, can harness 'vertical' leadership development through the delivery of 'heat experiences', 'colliding perspectives' and 'elevated sense-making, ${ }^{26}$

Heat experiences involve organisations taking calculated risks, and exposing leaders, who themselves must take a risk, to complex uncomfortable first-time challenges. Here, they are forced to grow, not just because they want to, but because there is a chance of failure, people are watching, and results matter. They are 'the what' that compels leaders to disrupt and disorient their traditional thinking styles, to discover new and better ways to make sense of the challenges they face. Caution must be excised, however, to get the 'temperature right', and control the heat within a safe space, with the right support, available at the right time, to help the individual stay within that learning 'sweet spot'. Importantly, there also needs to be an appropriate level of both individual and organisational tolerance of failure. ${ }^{27}$

Colliding perspectives expand the number of lenses through which a leader can analyse complexity and challenge their existing mental models. ${ }^{28}$ Individuals are encouraged to view the world through the eyes of different stakeholders, including that of patients, carers and other members of the multidisciplinary team, and by standing in their shoes, learn to identify and manage conflicting paradigms. Ideally combined with peer coaching, partnered with different disciplines, these colliding perspectives provide 'the who' that is inclusive and embraces a range of diverse thought. ${ }^{29}$
Elevated sense-making is the final piece, 'the how', that leads to transformational change. ${ }^{30}$ Not only must structured reflection (through reflective practice groups or action learning sets) be facilitated to allow leaders to reflect on their development over time and integrate their experiences with new found perspectives, but their development should be guided by experienced coaches or mentors.

It is vital that these three conditions are provided within postgraduate medical training, whether through activities embedded informally within the work environment, or formally via a targeted approach within leadership development programmes. Although value can still be extracted from opportunities that do not provide these conditions, leadership talent will remain untapped and dormant within healthcare organisations unless these are met. ${ }^{31}$

\section{Informal leadership development}

The common perception of leadership as an optional extra remains pervasive throughout the medical workforce. Combined with a 'curriculum lag', whereby there is a delay in implementing and adopting the latest evidence into training, the development of leadership competencies remains somewhat tokenistic. $^{32}$ The stars are aligning, however, and the importance of leadership development in both undergraduate and postgraduate medical curricula is slowly being realised. ${ }^{33}$

The message is clear. Leadership development does not begin or end at any particular stage of training. Leadership is for all doctors, at every stage, and should not be postponed until doctors are formally appointed to a leadership or management position. Leadership is rather a developmental process on a lifelong continuum, with individuals nurtured to help recognise and fulfil leadership roles, especially in the earliest of stages of their careers. ${ }^{34}$

Everyday leadership experiences are commonplace within psychiatric clinical settings, where decision-making is complex and ethical tensions arise through divergent views, roles and responsibilities within teams. ${ }^{35}$ Although often undervalued, these present opportune leadership development experiences where, among a range of other activities, leadership can be developed through acute crisis situations, multidisciplinary meetings, mentoring junior colleagues, medical education, clinical governance and quality improvement projects. It is important to recognise, name and make sense of these everyday leadership experiences within training, through supervision, and allow trainees to recognise the value of 'little l' leadership within their teams. ${ }^{36}$

More formal opportunities also exist through representative roles available locally, regionally and nationally, that can all lead on to providing more enhanced leadership experiences and the three primary conditions of vertical leadership development in their own right. Likewise, voluntary and additional professional activities can provide excellent leadership experience. For example, roles available within Royal Colleges, special interest groups, trade unions, healthcare regulators, the General Medical Council, or as a governor for healthcare and affiliated organisations.

Irrespective of the particular opportunity, whether formal or informal, obtaining feedback is critical for gaining insight into the trainees' own perception of their leadership 


\begin{tabular}{|c|c|}
\hline DONCS domain & DONCS descriptor \\
\hline Medical expert & $\begin{array}{l}\text { As a medical expert, the psychiatric leader integrates the other six intrinsic roles (as below) to negotiate complexity, } \\
\text { uncertainty and ambiguity, while contributing to continuous improvement and maintaining the highest standards of clinical } \\
\text { knowledge, person-centred care and professional values. }\end{array}$ \\
\hline Communicator & $\begin{array}{l}\text { As communicators, psychiatric leaders will develop trusted interpersonal relationships with and between individuals. They will } \\
\text { accurately elicit, synthesise and convey relevant information, in both oral and written form, to develop a shared understanding } \\
\text { between stakeholders of the relevant issues, problems and plans at hand. }\end{array}$ \\
\hline Collaborator & $\begin{array}{l}\text { As collaborators, psychiatric leaders will work effectively in partnership with patients, carers and extended multidisciplinary } \\
\text { teams of expert professionals. This will take place in multiple locations, within and across organisational boundaries, to deliver } \\
\text { optimal patient care and prevent, negotiate and resolve interpersonal conflict. }\end{array}$ \\
\hline Manager & $\begin{array}{l}\text { As managers, psychiatric leaders will participate in the improvement of healthcare delivery, manage resources appropriately, } \\
\text { develop competence in health informatics and contribute to the effectiveness of the team, organisation and system they work } \\
\text { within. }\end{array}$ \\
\hline $\begin{array}{l}\text { Health } \\
\text { advocate }\end{array}$ & $\begin{array}{l}\text { As health advocates, psychiatric leaders will promote diversity and inclusion. They will utilise their expertise and influence to } \\
\text { identify and advance the health and well-being of individual patients, communities and populations. }\end{array}$ \\
\hline Scholar & $\begin{array}{l}\text { As a scholar, the psychiatric leader pursues continuous personal and professional development. They will critically evaluate } \\
\text { information, facilitate and create a safe space for the mentoring and learning of others, and contribute to the creation, } \\
\text { dissemination and integration of evidence-based knowledge into practice. }\end{array}$ \\
\hline Professional & $\begin{array}{l}\text { As a professional, the psychiatric leader engages with healthcare regulation; maintains the highest standards of personal, } \\
\text { professional and ethical behaviour; embraces a compassionate and inclusive approach and is committed to reflective practice. } \\
\text { They support the well-being of both themselves and the staff around them. }\end{array}$ \\
\hline
\end{tabular}

DONCS, Direct Observation of Non-Clinical Skills.

capabilities, and the perceptions held by others of their behaviours and performance.

Integral tools within psychiatric training for facilitating such structured feedback are the Mini-Peer Assessment Tool and Direct Observation of Non-Clinical Skills (DONCS) workplace-based assessments. These are used across the General Medical Council-approved curricula for both core and specialty psychiatric training within the UK, to assess a trainees performance and allow trainees to demonstrate their leadership capabilities. ${ }^{37,38}$

Originally founded on The CanMEDS 2005 Physician Competency framework, ${ }^{39}$ DONCS are applicable to a range of diverse non-clinical skills, and structuring feedback on leadership experiences around the seven domains can at times feel convoluted and ambiguous.

Table 1 has been conceptualised from the evidence base to help suggest key competencies for psychiatric leaders within a DONCS assessment, and aims to support both trainees and trainers attaining and delivering feedback. ${ }^{39-42}$

\section{Formal leadership development}

There are a plethora of leadership development programmes, schemes and other opportunities available throughout the UK. This can be confusing for both trainees and trainers alike, occurring both in and out of training programmes, with a diverse range of requirements, levels of involvement and financial commitment.

Attempting to provide a brief description of these opportunities, Table 2 outlines a sample of the variety of leadership and management training that is currently available to psychiatric trainees within the UK. It is important to remember, however, that there is an almost constantly evolving stream of new opportunities depending on interests and geography, and that this table is likely to be quickly outdated.
Such formal leadership development could be conceptualised through a tiered approach (Fig. 1). Firstly, basic generic professional capabilities are provided in leadership for all doctors via an integrated approach within local training programmes. A second tier then provides enhanced local and regional leadership development offers for future service and divisional leaders. Then finally, at the upper tier, nationally coordinated, advanced programmes and fellowships, are delivered for aspiring organisational- and system-level leaders.

\section{Discussion}

It is important to note that leadership development does not suit a one-size-fits-all approach, and that the evidence does not suggest that any particular activity should be completed before another. ${ }^{3}$

Up to $90 \%$ of learning occurs informally, through often spontaneous, unstructured activities embedded within the work environment. ${ }^{62}$ As revealed through the developmental journeys of medical, clinical and managerial National Health Service chief executives, ${ }^{63}$ although formal leadership development can be transformational for some, it is insufficient in isolation.

Leadership development can often be better attributed to engagement with inspirational role models, and through the opportunistic experiences that emerging leaders seized because they could, and because they were motivated to make a difference.

For this very reason, it is vital that we overcome the shortage of role models with protected characteristics. Those in medical leadership positions must reflect the wider workforce and communities we serve. ${ }^{64}$ It is not permissible to allow ourselves to fall victim to a complex range of social, cultural, political, economic and historical factors, whether unconsciously or otherwise, that marginalise and disempower aspiring leaders from diverse backgrounds. 
Table 2 Leadership and management training availability to psychiatric trainees (correct as of 2020/21)

\begin{tabular}{|c|c|c|c|c|c|}
\hline & & & & Eligibility/target & Key points \\
\hline \multirow[t]{8}{*}{$\begin{array}{l}\text { Fellowships ( } 12 \\
\text { months) }\end{array}$} & \multirow[t]{6}{*}{$\begin{array}{l}\text { Outside of } \\
\text { local education } \\
\text { provider }\end{array}$} & \multirow[t]{4}{*}{ National } & $\begin{array}{l}\text { National Medical Directors } \\
\text { Clinical Fellow Scheme }\end{array}$ & $\begin{array}{l}\text { On completion of } \\
\text { the Foundation } \\
\text { Programme }\end{array}$ & $\begin{array}{l}\text { Funded, out of programme, centrally } \\
\text { recruited to national organisations. } \\
\text { Apprenticeship model, developed in } \\
\text { collaboration with UK Government and } \\
\text { arm's length bodies, mentored by senior } \\
\text { national leaders and undertake a range of } \\
\text { project and policy work. }\end{array}$ \\
\hline & & & $\begin{array}{l}\text { Welsh Clinical Leadership } \\
\text { Training Fellowship }{ }^{44, a}\end{array}$ & C/ST3 and above & \\
\hline & & & $\begin{array}{l}\text { Scottish Clinical Leadership } \\
\text { Fellowship Scheme } \\
\end{array}$ & C/ST2 and above & \\
\hline & & & $\begin{array}{l}\text { Northern Ireland (NIMDTA) } \\
\text { Achieve, Develop, Explore } \\
\text { Programme for Trainees } \\
(\text { ADEPT) })^{46, a}\end{array}$ & ST4 and above & \\
\hline & & \multirow[t]{2}{*}{$\begin{array}{l}\text { Local/ } \\
\text { regional }\end{array}$} & $\begin{array}{l}\text { Darzi Fellowship Programme - } \\
\text { London South Bank } \\
\text { University } 47, a\end{array}$ & C/ST3 and above & $\begin{array}{l}\text { Funded, out of programme, individually } \\
\text { recruited to local/regional organisations } \\
\text { through NHS Jobs. Undertake London } \\
\text { South Bank University PGCert in Leadership } \\
\text { in Health, alongside work-based fellowship } \\
\text { challenges. }\end{array}$ \\
\hline & & & $\begin{array}{l}\text { Future Leaders Programme - } \\
\text { Health Education Yorkshire and } \\
\text { Humber } 48, a\end{array}$ & C/ST3 and above & $\begin{array}{l}\text { Funded, out of programme, individually } \\
\text { recruited to local/regional organisations } \\
\text { through NHS Jobs. Undertake PGCert of } \\
\text { their choice, alongside work-based } \\
\text { fellowship challenges. }\end{array}$ \\
\hline & \multirow[t]{2}{*}{$\begin{array}{l}\text { Within local } \\
\text { education } \\
\text { provider }\end{array}$} & \multirow[t]{2}{*}{ National } & $\begin{array}{l}\text { Royal College of Psychiatrists' } \\
\text { Leadership and Management } \\
\text { Fellow Scheme } 49\end{array}$ & ST4 and above & $\begin{array}{l}\text { Sponsored, in programme experience, } \\
\text { utilising special interest time, individually } \\
\text { recruited to by local/regional organisations. } \\
\text { Face to face ( } 7 \text { days, London/Liverpool), } \\
\text { with work-based application. }\end{array}$ \\
\hline & & & $\begin{array}{l}\text { Royal College of Physicians' } \\
\text { (London) Chief Registrar } \\
\text { Programme }\end{array}$ & ST4 and above & $\begin{array}{l}\text { Funded, in or out of programme experience, } \\
\text { individually recruited to by local } \\
\text { organisations. Face to face ( } 5 \text { days, London/ } \\
\text { Liverpool) and } 40-50 \% \text { protected time to } \\
\text { practice leadership and quality } \\
\text { improvement. }\end{array}$ \\
\hline \multirow[t]{7}{*}{$\begin{array}{l}\text { Courses and } \\
\text { programmes }\end{array}$} & & \multirow[t]{6}{*}{ National } & $\begin{array}{l}\text { Royal College of Psychiatrists' } \\
\text { Leadership and Management } \\
\text { for Trainees and New } \\
\text { Consultants }\end{array}$ & Available to all & Self-funded, face to face (1 day). \\
\hline & & & $\begin{array}{l}\text { NHS Leadership Academy } \\
\text { Edward Jenner ( } 6 \text { weeks })^{52} \\
\end{array}$ & Available to all & $\begin{array}{l}\text { Free, online ( } 5 \text { h per week), with } \\
\text { work-based application. }\end{array}$ \\
\hline & & & $\begin{array}{l}\text { NHS Leadership Academy } \\
\text { Mary Seacole ( } 6 \text { months) or } \\
\text { Rosalind Franklin ( } 9 \text { months })^{52}\end{array}$ & $\begin{array}{l}\text { Core or higher } \\
\text { training, } \\
\text { respectively }\end{array}$ & $\begin{array}{l}\text { Predominantly self-funded (circa } \notin 1000 \text { ), } \\
\text { sponsorship and bursaries available ad hoc. } \\
\text { Online ( } 5 \text { h per week) and face to face } \\
\text { (Mary Seacole } 3 \text { days/Rosalind Franklin } 8 \\
\text { days - regional), with work-based } \\
\text { application. }\end{array}$ \\
\hline & & & $\begin{array}{l}\text { NHS Wales } 1000 \text { Lives } \\
\text { 'Improving Quality Together' }{ }^{53}\end{array}$ & Available to all & $\begin{array}{l}\text { Free, online (bronze) and face to face } \\
\text { (silver, } 2 \text { days), with work-based } \\
\text { application. }\end{array}$ \\
\hline & & & $\begin{array}{l}\text { Northern Ireland (NIMDTA) } \\
\text { ENGAGE Clinical Leadership } \\
\text { and Improvement } \\
\text { Programme }\end{array}$ & ST5 and above & Funded, face to face ( 1 day, 7 evenings). \\
\hline & & & $\begin{array}{l}\text { NHS Education for Scotland } \\
\text { Leadership and Management } \\
\text { Programme (LaMP) }\end{array}$ & C/ST3 and above & $\begin{array}{l}\text { Funded, online and face to face ( } 2 \text { days), } \\
\text { with work-based application. }\end{array}$ \\
\hline & & $\begin{array}{l}\text { Local/ } \\
\text { regional }\end{array}$ & $\begin{array}{l}\text { Learning to Lead - East } \\
\text { Midlands Leadership and }\end{array}$ & $\begin{array}{l}\text { On completion of } \\
\text { the Foundation } \\
\text { Programme }\end{array}$ & $\begin{array}{l}\text { Funded, face to face ( } 3 \text { days), with } \\
\text { work-based application through a }\end{array}$ \\
\hline
\end{tabular}




\begin{tabular}{|c|c|c|c|c|}
\hline & & & Eligibility/target & Key points \\
\hline & & $\begin{array}{l}\text { management programme } \\
(3 \text { years })^{56}\end{array}$ & & $\begin{array}{l}\text { multi-professional quality improvement } \\
\text { project. }\end{array}$ \\
\hline & & $\begin{array}{l}\text { Chief Residents' Management } \\
\text { and Leadership Programme - } \\
\text { Health Education East of } \\
\text { England }^{57}\end{array}$ & ST5 and above & $\begin{array}{l}\text { Funded, centrally recruited, face to face } \\
\text { (10-day Judge Business School } \\
\text { 'mini-MBA'), with work-based application } \\
\text { and supported leadership role. }\end{array}$ \\
\hline \multirow[t]{2}{*}{$\begin{array}{l}\text { Postgraduate } \\
\text { education }\end{array}$} & $\begin{array}{l}\text { Master's in Medical } \\
\text { Leadership (MSc) }\end{array}$ & $\begin{array}{l}\text { Various institutions offer } \\
\text { 'step-on, step-off approach' } \\
\text { from PGCert to PGDip to MSc } \\
(1-3 \text { years })^{58,59}\end{array}$ & Available to all & $\begin{array}{l}\text { Predominantly self-funded ( } € 2500- \\
£ 25000 \text { ), sponsorship and bursaries } \\
\text { available. Part time, moderate workload, } \\
\text { variable online versus face to face. }\end{array}$ \\
\hline & $\begin{array}{l}\text { Master's in Business } \\
\text { Administration (MBA) }\end{array}$ & $\begin{array}{l}\text { Various institutions, some offer } \\
\text { healthcare specialties or NHS } \\
\text { endorsement ( } 2-3 \text { years) }\end{array}$ & Available to all & $\begin{array}{l}\text { Predominantly self-funded ( } € 15000- \\
£ 90000) \text {, sponsorship and bursaries } \\
\text { available. Part time, heavy workload, } \\
\text { variable online versus face to face. }\end{array}$ \\
\hline
\end{tabular}

NIMDTA, Northern Ireland Medical \& Dental Training Agency; NHS, National Health Service; PGCert, Postgraduate Certificate; MBA, Master of Business Administration; MSc, Master of Science; PGDip, Postgraduate Diploma.

a. Predominantly non-clinical (although some do allow limited ongoing clinical activity), and therefore often require an extension to training via out-of-programme experience approval.

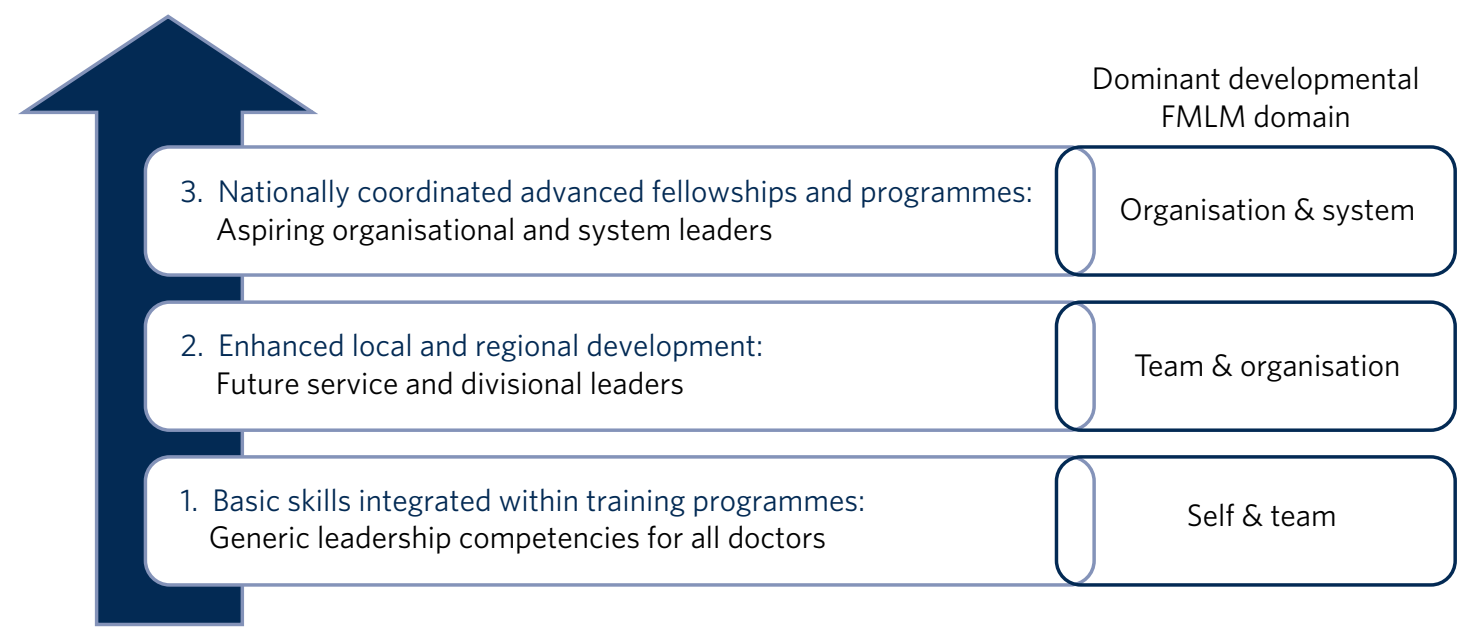

Fig. 1 A tiered approach to leadership development. FMLM, Faculty of Medical Leadership and Management.

Equality and diversity should be a top priority for all individuals and organisations. We must counteract the deeply embedded prejudice and discrimination that have become endemic within modern society. ${ }^{65}$ No matter what the characteristic, whether it be gender, sexual orientation, race, religion or any other characteristic that differs from the majority of leaders, these individuals do not easily fit within a structure that is coded towards the 'snowy white peaks of the NHS', ${ }^{66}$ and this must be overcome.

To build this diversity into our psychiatric leadership, and that we need within our mental health services, we must embrace the 'lived experience' of talented leaders regardless of demographic differences, and adopt an inclusive leadership approach. ${ }^{67,68}$ After all, organisations with greater inclusion, rather than merely diversity, are proven to perform better, with greater improvement and innovation, higher levels of morale, and new insights that maximise the potential of employees. ${ }^{68,69}$
As Vernā Myers puts it 'Diversity is being invited to the party; inclusion is being asked to dance, ${ }^{70}$

Multiple strategies can be employed to improve diversity and develop an inclusive approach, ${ }^{65-72}$ but it is no easy task. Fundamentally, it is a cultural change. All doctors, and particularly existing leaders, must engage with these groups, create a psychologically safe space, listen to their stories, confront the hard truths laid bare by their experiences, and challenge the status quo, making diversity and inclusion a personal priority. Allies from non-disadvantaged or less discriminated against groups can confront and have a powerful impact on the behaviour of others. They must not just question what privileges they have been afforded that others might not, but question and reflect on the absence of challenges and barriers that they have not had to overcome but others might. Crucially, they must then act, working within the organisation and system to counteract and mitigate these for others. 
Individuals should not feel like 'outsiders'. We should rather recognise an individual's need to belong and proactively seek role models with greater diversity, to make the inclusion of leaders with protected characteristics explicit and visible. This allows those from marginalised groups to identify with the existing leadership, see themselves as leaders and, crucially, feel empowered to seize those opportunistic leadership experiences that are so crucial for their development. In combination, active career sponsorship will be crucial to retain and advance their leadership talent, with mentorship being a powerful mechanism for both the individual and the organisation. ${ }^{68,73}$

It truly is an inclusive leadership approach that is required. Demographic diversity in isolation, is insufficient. Active role-modelling and the support of key allies in existing leadership positions is essential to provide equitable access to formal and informal leadership development.

Just as we would expect within clinical practice, trainees of all backgrounds must be supported by experienced trainers who expose them to increasingly uncomfortable challenges, yet who provide them with the psychological safety net to take risks, experiment and develop 'on the job'.

\section{Conclusions}

Mental health services face unprecedented challenges on an almost daily basis. To survive in this world, and lead quality improvement towards more preventative, holistic and personalised care, doctors must develop a deep understanding of leadership and effectively demonstrate the core values and behaviours expected of medical professionals.

Greater attention must be paid towards medical leadership development and an inclusive approach, whereby all doctors, from every background, are supported to advance. This has never been more important. The view of leadership development being an optional extra within medicine, or a skill set to be developed later in a medical professional's career, is outdated.

No matter which one of the many diverse interventions are pursued, doctors must engage with, and be supported in, both informal and formal leadership development. This is a collective responsibility, and much more must be done to ensure equity of access to leadership development for all, from the earliest of stages in a doctor's career.

\section{About the authors}

Dr Alex Till (MBChB, MRCPsych, MSc, MBA) is a Specialty Registrar in Forensic Psychiatry with Health Education England - North West, UK. Dr Radhika Sen (BSc, MBChB, MRCPsych) is a Consultant Psychiatrist in General Adult and Old Age Psychiatry with Camden and Islington NHS Foundation Trust, UK; and a Leadership and Management Fellow (2019/ 20) with the Royal College of Psychiatrists, UK. Dr Helen Crimlisk (FRCPsych, MSc, FAcadMEd) is Deputy Medical Director of Sheffield Health and Social Care NHS Foundation Trust, UK; an Associate Registrar for Leadership and Management with the Royal College of Psychiatrists, UK; and a Generation Q Fellow with The Health Foundation, UK.

\section{Author contributions}

We confirm that all authors meet the four ICMJE criteria for authorship, being equally involved in the design, drafting and revision of the article.

\section{Declaration of interest}

None.

\section{References}

1 Tooke J. Aspiring to Excellence. Findings and Final Recommendations of the Independent Inquiry into Modernising Medical Careers. Modernising Medical Careers Inquiry, 2008 (https://www.mmcinquiry.org.uk/).

2 Health Education England. Future Doctor. Health Education England, 2020 (https://hee.nhs.uk/our-work/future-doctor).

3 West M, Armit K, Loewenthal L, Eckert R, West T, Lee A. Leadership and Leadership Development in Healthcare: The Evidence Base. The Faculty of Medical Leadership and Management, The Center for Creative Leadership and The King's Fund, 2015 (https://www.kingsfund.org. uk/publications/leadership-and-leadership-development-health-care).

4 West M, Eckert R, Collins B, Chowla R. Caring to Change: How Compassionate Leadership Can Stimulate Innovation in Health Care. The King's Fund, 2017 (https://www.kingsfund.org.uk/publications/caring-change).

5 Care Quality Commission. The State of Health Care and Adult Social Care in England 2017/18. Care Quality Commission, 2018 (https://www.cac. org.uk/news/stories/state-care-201718-published).

6 Northouse P. Leadership: Theory and Practice Third Edition. Sage Publications, 2004.

7 Swanwick T. Leadership and management: what's the difference? BM Leader 2019; 3: 99-100.

8 McKimm J, Vogan CL. Followership: much more than simply following the leader. BMJ Leader 2020; 4: 41-4.

9 General Medical Council. Leadership and Management for All Doctors. General Medical Council, 2012 (https://www.gmc-uk.org/ethical-guid ance/ethical-guidance-for-doctors/leadership-and-management-forall-doctors).

10 General Medical Council. Outcomes for Graduates. General Medical Council, 2018 (https://www.gmc-uk.org/education/standards-guidance-and-curricula/standards-and-outcomes/outcomes-for-graduates).

11 General Medical Council. Generic Professional Capabilities Framework. General Medical Council, 2017 (https://www.gmc-uk.org/education/ standards-guidance-and-curricula/standards-and-outcomes/genericprofessional-capabilities-framework)

12 Faculty of Medical Leadership and Management. Leadership and Management Standards for Medical Professionals Third Edition. Faculty of Medical Leadership and Management, 2021 (https://www.fmlm.ac. $\mathrm{uk} /$ standards).

13 Clark J. Medical leadership and engagement: no longer an optional extra. J Health Organ Manag 2012; 26: 437-43.

14 Powell A, Davies H. Managing Doctors, Doctors Managing. Nuffield Trust, 2016 (https://www.nuffieldtrust.org.uk/research/managing-doctorsdoctors-managing)

15 Creed D, Dejordy R, Lok J. Being the change: resolving institutional contradiction through identity work. Acad Manage J 2010; 53(6): 1336-64.

16 McGivern G, Currie G, Ferlie E, Fitzgerald L, Waring J. Hybrid manager-professionals' identity work: the maintenance and hybridization of medical professionalism in managerial contexts. Public Adm 2015; 93(2): 412-32.

17 Goodall $\mathrm{AH}$, Stoller JK. The future of clinical leadership: evidence for physician leadership and the educational pathway for new leaders. BMJ Leader 2017; 1: 8-11.

18 Sarto F, Veronesi G. Clinical leadership and hospital performance: assessing the evidence base. BMC Health Serv Res 2016; 16: 169.

19 Dickinson H, Ham C. Engaging Doctors in Leadership: Review of the Literature. NHS Institute for Innovation and Improvement and the University of Birmingham Health Services Management Centre: Coventry, 2008 (https://www.birmingham.ac.uk/Documents/collegesocial-sciences/social-policy/HSMC/research/leadership-literaturereview.pdf). 
20 Spurgeon P, Mazelan PM, Barwell F. Medical engagement: a crucia underpinning to organizational performance. Health Serv Manage Res 2011; 24(3): 114-20

21 Bennett N, Lemoine GJ. What VUCA really means for you. Harvard Business Review, 2014 (https://hbr.org/2014/01/what-vuca-reallymeans-for-you).

22 Perry J, Mason F. The value of psychiatrists in leadership and management. BJPsych Adv 2016; 22: 263-8.

23 Beer $M$, Finnstrom M, Schrader D. Why leadership training fails - and what to do about it. Harv Bus Rev 2016; 94(10): 50-7.

24 Edmondson AC, Woolley AW. Understanding outcomes of organizational learning interventions. In International Handbook on Organizational Learning and Knowledge Management (eds M Easterby-Smith, M Lyles). Blackwell, 2003.

25 Petrie N. Vertical Leadership Development - Part 1. Developing Leaders for a Complex World. Center for Creative Leadership, 2014 (http://www. ccl.org/wp-content/uploads/2015/04/VerticalLeadersPart1.pdf).

26 Petrie N. The How-To of Vertical Leadership Development - Part 2. 30 Experts, 3 Conditions and 15 Approaches. Center for Creative Leadership, 2015 (https://www.ccl.org/wp-content/uploads/2015/ 04/verticalLeadersPart2.pdf).

27 Waltz C. Turn Up the Heat, Turn Up the Learning - How to Fire Up Your People without Burning Them Out. Centre for Creative Leadership, 2019 (https://www.ccl.org/wp-content/uploads/2019/05/turn-up-heatturn-up-learning-heat-experiences-for-development-center-for-creative-leadership.pdf)

28 Isles V, Sutherland K. Organisational Change: A Review for Health Care Managers, Professionals and Researchers. National Coordinating Centre for the Service Delivery and Organisation Research Programme, London School of Hygiene \& Tropical Medicine 2001

29 Diaz-Uda A, Medina C, Schill B. Diversity's New Frontier - Diversity of Thought and the Future of Workforce. Diaz Deloitte University Press, 2013 (https://www2.deloitte.com/us/en/insights/topics/talent/ diversitys-new-frontier.html)

30 Rooke D, Torbert R. 7 Transformations of Leadership. Harv Bus Rev 2015; 83(4): 66-133.

31 Rafferty J, Till A. Nurturing leadership talent today for the benefit of tomorrow. Health Serv J 2016 (https://www.hsi.co.uk/workforce/nurturingleadership-talent-today-for-the-benefit-of-tomorrow/7009372.article).

32 Till A, Anandaram A, Dapaah A, Ibrahim R, Kansagra A, Prasad R, et al Postgraduate leadership development: a cross specialty trainees' perspective. BMJ 2016; 352: i374.

33 Till A, McKimm J, Swanwick T. The importance of leadership development in medical curricula: a UK perspective (stars are aligning). $J$ Healthc Leadership 2020; 12: 19-25.

34 Swanwick T. Leadership Development for Doctors in Postgraduate Medica Training. Health Education England, 2017 (https://www.hee.nhs.uk/ our-work/leadership/leadership-development-doctors-postgraduatemedical-training).

35 Silva $E$, Till A, Adshead G. Ethical dilemmas in psychiatry: when teams disagree. BJPsych Adv 2017; 23: 231-9.

36 Bohmer R. Leadership with a small "I". BMJ 2010; 340: c483.

37 Conference of Postgraduate Medical Deans (UK). Gold Guide 8th Edition. A Reference Guide for Postgraduate Foundation and Specialty Training in the UK. Conference of Postgraduate Medical Deans (UK), 2020 (https://www.copmed.org.uk/gold-guide-8th-edition/).

38 Royal College of Psychiatrists. GMC Approved Curricula. Royal College of Psychiatrists, 2020 (https://www.rcpsych.ac.uk/training/curriculaand-guidance/gmc-approved-curriculum-modules).

39 Frank JR, ed. The CanMEDS 2005 Physician Competency Framework: Better Standards. Better Physicians. Better Care. Royal College of Physicians and Surgeons of Canada, 2005.

40 Frank JR, Snell L, Sherbino J, eds. CanMEDS 2015 Physician Competency Framework. Royal College of Physicians and Surgeons of Canada, 2015.

41 Royal College of Psychiatrists. Role of the Consultant Psychiatrist. Leadership and Excellence in Mental Health Services (OP74). Royal
College of Psychiatrists, 2010 (https://www.rcpsych.ac.uk/docs/ default-source/members/supporting-you/startwell/startwell-clinicalleadership-op74.pdf?sfvrsn=8b6e1f_12).

42 Royal College of Psychiatrists. Core Values for Psychiatrists (CR204). Royal College of Psychiatrists, 2017 (https://www.rcpsych.ac.uk/members/supporting-you/new-consultants-startwell).

43 Faculty of Medical Leadership and Management. National Medical Director's Clinical Fellow Scheme. Faculty of Medical Leadership and Management, 2021 (https://www.fmlm.ac.uk/programme-services/ individual-support/national-medical-directors-clinical-fellow-scheme).

44 Health Education and Improvement Wales. Welsh Clinical Leadership Training Fellowship. Health Education and Improvement Wales 2021 (https://heiw.nhs.wales/support/qist/welsh-clinical-leadershiptraining-fellowship-wcltf/).

45 Scotland Deanery. The Scottish Clinical Leadership Fellowship. Scotland Deanery, 2021 (https://www.scotlanddeanery.nhs.scot/your-development/leadership-and-management-development/scottish-clinicalleadership-fellowship-scheme/).

46 Northern Ireland Medical and Dental Training Agency. ADEPT - (Achieve Develop Explore Programme for Trainees. Northern Ireland Medical and Dental Training Agency, 2021 (https://www.nimdta.gov.uk/adept/)

47 London South Bank University. Darzi Fellowship. London South Bank University, 2020 (https://www.lsbu.ac.uk/business/research-enterprise-and-innovation/health-systems-innovation-lab/what-we-do/ darzi-fellowship-challenge)

48 Health Education England (Yorkshire and Humber). Future Leaders Programme. Health Education England (Yorkshire and Humber) 2021 (https://www.yorksandhumberdeanery.nhs.uk/education/ future_leaders_programme).

49 Royal College of Psychiatrists. Royal College of Psychiatrists Leadership and Management Fellow Scheme. Royal College of Psychiatrists, 2020 (https://www.rcpsych.ac.uk/training/your-training/leadershipand-management-training).

50 Royal College of Physicians. Chief Registrar Programme. Royal College of Physicians (London), 2021 (https://www.rcplondon.ac.uk/projects/ chief-registrar-programme).

51 Royal College of Psychiatrists. Royal College of Psychiatrists' Leadership and Management for Trainees and New Consultants. Royal College of Psychiatrists, 2021 (https://www.rcpsych.ac.uk/events).

52 NHS Leadership Academy. Leadership Programmes. NHS Leadership Academy, 2021 (https://www.leadershipacademy.nhs.uk/programmes/).

53 Improvement Academy Wales. Improving Quality Together. Improvement Academy Wales, 2019 (https://iqt.wales.nhs.uk/).

54 Northern Ireland Medical and Dental Training Agency. ENGAGE Clinical Leadership and Improvement Programme. Northern Ireland Medical and Dental Training Agency, 2021 (https://www.nimdta.gov.uk/traineeopportunities/engage-clinical-leadership-improvement-programme/).

55 Scotland Deanery. Leadership and Management Programme. Scotland Deanery, 2021 (https://www.scotlanddeanery.nhs.scot/your-development/leadership-and-management-development/leadership-andmanagement-programme-lamp/).

56 Health Education England. Learning to Lead - East Midlands Leadership and management programme. Health Education England (East Midlands), 2021 (https://www.eastmidlandsdeanery.nhs.uk/faculty/ training-courses/leadership-management-programme).

57 Cambridge University Hospitals Post Graduate Medical Centre \& Judge Business School. Cambridge Chief Resident Management and Leadership Development Programme. Cambridge University Hospitals Post Graduate Medical Centre \& Judge Business School, 2021 (https:// www.cam-pgmc.ac.uk/specialties/cambridge-chief-resident-management-and-leadership-development-programme).

58 Edge Hill University. MSc Leadership Development. Edge Hill University, 2021. (https://www.edgehill.ac.uk/courses/leadershipdevelopment/).

59 Swansea University. Leadership for the Health Professions, MSc/PGDip/ PGCert. Swansea University, 2021. (https://www.swansea.ac.uk/postgraduate/taught/medicine/leadership-for-the-health-professions/). 
60 Warwick Business School. Master of Business Administration. Warwick Business School, 2021 (Warwick Business School. Master of Business Administration. https://www.wbs.ac.uk/courses/mba/).

61 NHS Leadership Academy. NHS Masters in Business Administration (MBA) Programme. NHS Leadership Academy, 2017 (https://www.leadershipacademy.nhs.uk/news/new-nhs-mba/).

62 Rabin R. Blended Learning for Leadership: The CCL Approach. Centre for Creative Leadership, 2014 (https://www.ccl.org/wp-content/ uploads/2015/04/BlendedLearningLeadership.pdf).

63 Till A McGivern G. Routes to the top: the developmental journeys of medical, clinical and managerial NHS chief executives. BMJ Leader 2020; 4: 64-8.

64 Cornwall PL, Osborne A. Psychiatrists on boards: the diversity of psychiatrists working as board directors in Mental Health Trusts in England. BMJ Leader [Epub ahead of print] 16 Dec 2020. Available from: https://doi.org/10.1136/leader-2020-000348.

65 Royal College of Psychiatrists. RCPsych Equality Action Plan 2021-23. Royal College of Psychiatrists, 2021 (https://www.rcpsych.ac.uk/ about-us/equality-diversity-and-inclusion/equality-action-plan).

66 Kline R. The Snowy White Peaks of the NHS: A Survey of Discrimination in Governance and Leadership and the Potential Impact on Patient Care in London and England. Middlesex University, 2014 (https://www.mdx. ac.uk/_data/assets/pdf_file/0015/50190/The-snowy-white-peaksof-the-NHS.pdf)
67 Kline R. Leadership in the NHS. BMJ Leader 2019; 3: 129-32.

68 Bolden R, Adelaine A, Warren S, Gulati A, Conley H, Jarvis C. Inclusion: The DNA of Leadership and Change - A Review of Theory, Evidence and Practice on Leadership, Equality, Diversion and Inclusion in the National Health Service. NHS Leadership Academy and University of the West of England, 2019 (https://www.leadershipacademy.nhs.uk/resources/ inclusion-equality-and-diversity/blfi-2/)

69 West MA, Kaur M, Dawson JF. Making the Difference: Diversity and Inclusion in the NHS. The King's Fund, 2015 (https://www.kingsfund. org.uk/publications/making-difference-diversity-inclusion-nhs).

70 Myers VA. Moving Diversity Forward. American Bar Association 2011.

71 Sealy R. NHS Women on Boards 50:50 by 2020: Action for Equality - The Time Is Now. NHS Confederation, 2020 (https://www.nhsconfed.org/ news/2020/09/action-for-equality-the-time-is-now).

72 NHS England and NHS Improvement. A Model Employer: Increasing Black and Minority Ethnic Representation at Senior Levels Across the NHS. NHS Workforce Race Equality Standard (WRES) Leadership Strategy. NHS England, 2019 (https://www.england.nhs.uk/publication/a-modelemployer/)

73 Thomas DA. The truth about mentoring minorities. Race matters. Harv Bus Rev 2001; 79(4): 98-107, 168.

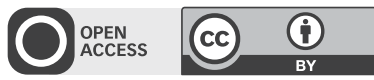

\title{
EDUCATION AND TRAINING
}

\section{'Choose Psychiatry' goes virtual: experiences and learning from the online 2020 National Psychiatry Summer School}

\author{
Patricia Vinchenzo, (1) Nikki Nabavi, ${ }^{2}$ Derek K. Tracy ${ }^{3,4,5}$ []
}

BJPsych Bulletin (2022) 46, 181-187, doi:10.1192/bjb.2021.42

\author{
Queen's University Belfast, UK \\ ${ }^{2}$ University of Manchester, UK; ${ }^{3}$ Oxleas \\ NHS Foundation Trust, London, UK: \\ ${ }^{4}$ Institute of Psychiatry, Psychology \& \\ Neuroscience, King's College London, \\ UK; ${ }^{5}$ Department of Psychiatry, \\ University College London, UK \\ Correspondence to Patricia Vinchenzo \\ (pvinchenzo01@qub.ac.uk) \\ First received 30 Nov 2020, final \\ revision 7 Mar 2021, accepted \\ 26 Mar 2021 \\ (c) The Author(s), 2021. Published by \\ Cambridge University Press on behalf of \\ the Royal College of Psychiatrists. \\ This is an Open Access article, distributed \\ under the terms of the Creative \\ Commons Attribution licence (http:// \\ creativecommons.org/licenses/by/4.0/) \\ which permits unrestricted re-use, \\ distribution, and reproduction in any \\ medium, provided the original work is \\ properly cited.
}

Aims and method COVID-19 has forced many educational events to go 'virtual'. We report on the first online student-run National Psychiatry Summer School (NPSS). Evaluation of the online format and content was undertaken through survey feedback from almost 400 attendees.

Results The NPSS positively affected attendees' perceptions of psychiatry as a career choice. The virtual format was positively received, with benefits including breaking down traditional barriers of geography and cost.

Clinical implications Post-COVID-19, a hybrid future of mixed virtual and face-to-face events is likely. Our work shows the viability of this and unique gains it might offer, and offers experiential learning on challenges encountered for others who wish to trial further virtual conferences.

Keywords PsychSoc; psychiatry society; recruitment; summer school; virtual conference. 